\title{
Entrepreneurial Intentions of Women: A literature review
}

\author{
Bhairab Chandra Patra*, Usha Lenka**
}

Entrepreneurial intentions research has been steadily growing and has recently gained more momentum in the twenty-first century. But the field of women entrepreneurial intentions is still in a very nascent stage and lots of research work needs to be done on the entrepreneurial intentions of women. This study attempts to review the literature on entrepreneurial intentions of women and provide necessary actions to be taken. The purpose of this study is to identify the main sub-areas on which women entrepreneurial intentions research is being conducted by the researchers. The Author uses citation analysis as a tool for identifying the fields attracting the maximum attention of researchers and content analysis to find out the gist of research in each sub-area. Cross referencing method was also used to find the papers in the field that proved most impactful and have made significant changes in the advancement of the field. Each paper was analyzed in terms of its objectives, findings, and future scope. The study presents an insight of the area from the review. It also highlights the major gaps identified from academic literature.

Keywords: entrepreneurial intentions, entrepreneurial decision-making process, citation analysis, content analysis.

Submitted: 10.09 .18 | Accepted: 14.12.18

\section{Intencje przedsiębiorcze kobiet: przegląd literatury}

Badania nad intencjami przedsiębiorczości stale się rozwijaja $i$ w ostatnich latach XXI $w$. nabraty tempa. Obszar badań nad intencjami przedsiębiorczymi kobiet jest jednak nadal rzadko poruszany $i$ wymaga kolejnych prac badawczych. Niniejsze badanie ma na celu dokonanie przegladu literatury dotyczacego intencji przedsiębiorczych kobiet i przygotowanie rekomendacji do dalszych kierunków badań działań, które warto bytoby podjać. Celem tego badania jest zidentyfikowanie gtównych obszarów, w których naukowcy prowadza badania dotyczace intencji przedsiębiorczych kobiet. Autor wykorzystuje analizę cytowań jako narzędzie do identyfikacji obszarów, które skupiaja największa uwage naukowców oraz analizę treści, aby znaleźć sedno badań w każdym z analizowanych obszarów. Wykorzystano równiė̇ metodę porównawcza do znalezienia prac, które okazaty się najbardziej wplywowe i przyczy-

\footnotetext{
* Bhairab Chandra Patra - Department of Management Studies, Indian Institute of Technology Roorkee. Correspondence address: Roorkee - Haridwar Highway, Roorkee, Uttarakhand, India, Pin-247667, e-mail: bhairab.official@gmail.com, ORCID: 0000-0002-9237-0345.

** Usha Lenka - Dr., Department of Management Studies, Indian Institute of Technology Roorkee. Correspondence address: Roorkee - Haridwar Highway, Roorkee, Uttarakhand, India, Pin-24766, e-mail: ushalenka@gmail.com.
} 
nity się do znaczacych zmian w zaawansowaniu tego obszaru badawczego. Każdy artykut byt analizowany pod katem jego celów, wniosków i rekomendacji. Autor wytania również gtówne luki badawcze zidentyfikowane na podstawie analizy literatury naukowej.

Słowa kluczowe: intencje przedsiębiorcze, proces podejmowania decyzji przedsiębiorczych, analiza cytowań, analiza treści.

Nadesłany: 10.09.18 | Zaakceptowany do druku: 14.12.18

JEL: L26, J16

\section{Introduction}

The research on entrepreneurial intentions has been growing at a steady rate since its conception by the founding works of Shapero (1984). But the concept was completely established after combining the research on behavior model (Ajzen, 1991; Bandura, 1982) from the field of social psychology. The profounding work of Kolvereid (1996a,b) in his two papers apportioned to integrating the fields of social psychology and entrepreneurship. Since then there has been a proliferating research on entrepreneurial intentions but the amount of research conducted on women entrepreneurial intentions has been considerably less. A significant gender gap in research is evident. The behavioral attributes of women are considerably different from men and need specific research concentrating on women. Men have a higher entrepreneurial tendency owing to the societal construct.

Studies have been conducted extensively to recognize all the antecedents, moderators, factors and variables that affect the entrepreneurial intentions but only limited papers focusing purely on entrepreneurial intentions of women have been published to date. Despite the fact that there are well established models on entrepreneurial intentions which have been extensively applied by the researchers on entrepreneurs, still there is a need for establishment of intentions model for evaluation of entrepreneurial intentions of women as research has already proven that there is a lot of difference in the thought process between women and men. So this one size fits all approach cannot be applied to evaluate the entrepreneurial intentions of women. Also, proper alignment and systemization of research is required for the advancement of research in this field, so categorization of research and segregation of all the research papers in major categories and their subcategories would help future researchers to better identify the problems in research. These divisions of research papers will also help to identify what is the current need of research and will also provide an ease of access to the researchers. Identifying the current trends through these categories will also help in prioritizing particular categories or sub-categories based on their demand. This would help to identify gaps in research and areas on which further research can be done.

In India most of the early-stage entrepreneurs are in the age group of 18 to 44 years and around one third (34 percent) are women (GEM report). Surveys conducted by the global entrepreneurship monitor reveal that early stage entrepreneurial actions are influenced by gender and men are more likely to take entrepreneurship than their women counterparts.

The intention of carrying out a given behavior may be affected by several factors, such as needs, values, wants, habits, and beliefs (Bird, 1988; Lee and Wong, 2004). Prior research has shown that the entrepreneurial intentions of individuals are influenced by three motivational constructs i.e., perceived behavioral control, subjective norms, and personal attraction (Liñán, 2008). Self-efficacy is also seen to be a major driver of entrepreneurial intentions in women.

\section{Methodology}

Research on entrepreneurial intentions of women is still in its nascent stage but still an attempt has been done 
in this paper to analyze the most recent literature available on entrepreneurial intentions of women to identify the major areas and trends of research. To ensure the transparency and systemacity which leads to replicability, the prescribed methodological recommendations by earlier researchers have been followed (Tranfield., Denyer and Smart, 2003). The major criteria for inclusion of papers was that the article should have been published in a journal, as journals are considered to be validated and reliable source of information (Podsakoff et al., N. 2005). On the opposite, due to the criteria applied, books, chapters and conference papers were eliminated as they feature restricted access and variable peer review process (Jones et al., 2011).

Preliminary Search on Scopus in all fields of papers available in database resulted in 3335 papers. Now the search was restricted to article title, abstract and keywords to increase the relativity of papers to the subject and also to reduce the enormous volume which returned 194 papers. Scopus was selected for first search due to the enormous size of its database. Then the research was filtered by restricting of type of document to search only "articles" and "review papers". Conference papers, book chapters and articles in press were excluded in the type of document search which returned 142 papers. Next, a citation analysis was done to find out the most referenced and most impacting papers in the field. Out of 142 papers only 108 were cited at least once.

Basic search on "Science direct" gave a total of 1452 results. Next, only research articles and review articles were included and the book chapters, encyclopedia, conference papers and book reviews were excluded. This search yielded 1099 papers. The Procedia papers were also excluded which returned 892 results. The search was limited to title and abstract reduced the search to 86 papers out of which 49 had been cited earlier.

Search on "Proquest" did not render any relevant document so it was excluded from search for papers.

Search on Google Scholar returned a total of 87,400 results. So the search was restricted to filtering in the title of the paper, so the results were reduced to 43 . Out of 43 papers only 25 had citations.

Initial search on web of science returned 56 results. The analysis for citations showed that 29 out of the 56 papers had been cited earlier.

This way the preliminary research returned a total of 211 papers out of which 86 were found redundant and 28 more were in a different language. 59 papers were found not relevant to the topic of research. After complete screening, 38 papers were found from journals which were relevant to the topic of entrepreneurial intentions of women and had already been cited by earlier researchers.

Now cross-referencing method was used in above papers to find the most impactful papers in the field which gave additional 4 papers. 3 more research papers were included in the paper on the advice of the experts in the field which were found to be impactful.

Finally, the total of 45 papers were shortlisted based on all the above mentioned criteria.

\subsection{Analysis of papers}

The 45 shortlisted papers were now reviewed intensively by the researchers independently and major areas of research on entrepreneurial intentions of women were identified after both the authors reached an agreement on the segregation of the topics. After complete analysis and agreement of both authors, five major areas of research were identified on which earlier researchers had focused. These five major sub-categories of papers are Concepts and Models, Individual Level Variables, Entrepreneurial Training and Education, Environmental Variables, and Entrepreneurial Mechanism. These five categories were again sub-divided into 24 smaller categories. All 45 papers which were shortlisted earlier were segregated into the 5 major categories and 24 sub-categories by the authors independently and then discussion was carried out in case the authors had different opinions about the category or sub-category of a specific paper.

The research papers with citations which were segregated into the five major categories after the analysis and agreement of authors are provided below: 
Table 1. Research papers in the category of Concepts and Models

\begin{tabular}{|c|l|r|l|}
\hline Sl. No. & \multicolumn{1}{|c|}{ Author(year) } & Cites & \multicolumn{1}{|c|}{ Journal } \\
\hline 1. & Boyd and Vozikis (1994) & 1733 & ETP \\
\hline 2. & BarNir, Watson and Hutchins (2011) & 256 & JASP \\
\hline 3. & Kickul, Wilson, Marlino and Barbosa (2008) & 165 & JSBD \\
\hline 4. & Haus, Steinmetz, Isidor and Kabst (2013) & 81 & IJGE \\
\hline 5. & Sweida and Reichard (2013) & 37 & JSBED \\
\hline 6. & Varamäki, Joensuu, Tornikoski and Viljamaa (2015) & 13 & JSBED \\
\hline 7. & Tsai, Chang and Peng (2016) & 12 & IEMJ \\
\hline 8. & Smith, Sardeshmukh and Combs (2016) & 9 & ET \\
\hline 9. & Kennedy and Drennan (2002) & 6 & SER \\
\hline 10. & Zeffane (2015) & 2 & JEC \\
\hline 11. & Srivastava and Misra (2017) & 2 & JEEE \\
\hline 12. & Wheadon and Duval-Couetil (2017) & IJGE \\
\hline
\end{tabular}

Source: authors' analysis from Google Scholar.

Table 2. Research papers in the category of Entrepreneurial Training and Education

\begin{tabular}{|c|l|c|l|}
\hline Sl. No. & \multicolumn{1}{|c|}{ Author(year) } & Cites & \multicolumn{1}{|c|}{ Journal } \\
\hline 1. & Wilson, Kickul and Marlino (2007) & 1187 & ETP \\
\hline 2. & Bae, Qian, Miao and Fiet (2014) & 408 & ETP \\
\hline 3. & Zhang, Duysters and Cloodt (2014) & 206 & IEMJ \\
\hline 4. & Wilson, Kickul, Marlino, Barbosa and Griffiths (2009) & 101 & JDE \\
\hline 5. & Westhead and Solesvik (2016) & 43 & ISB \\
\hline 6. & Pruett (2012) & 29 & JEB \\
\hline 7. & Rauth Bhardwaj (2014) & 23 & JEEE \\
\hline 8. & Entrialgo and Iglesias (2016) & 17 & IEMJ \\
\hline
\end{tabular}

Source: authors' analysis from Google Scholar.

Table 3. Research papers in the category of Environmental Variables

\begin{tabular}{|c|l|r|l|}
\hline Sl. No. & \multicolumn{1}{|c|}{ Author(year) } & Cites & \multicolumn{1}{|c|}{ Journal } \\
\hline 1. & Liñán and Chen (2009) & 1419 & ETP \\
\hline 2. & Langowitz and Minniti (2007) & 905 & ETP \\
\hline 3. & Scherer, Brodzinski and Wiebe (1990) & 332 & JSBM \\
\hline 4. & Liñán and Santos (2007) & 309 & IAER \\
\hline 5. & Santos, Roomi and Liñán (2016) & 58 & JSBM \\
\hline 6. & Gallant, Majumdar and Varadarajan (2010) & 17 & EBS \\
\hline 7. & Austin and Nauta (2016) & 16 & IJESB \\
\hline 8. & Iakovleva and Solesvik (2014) & 14 & IEMJ \\
\hline 9. & $\begin{array}{l}\text { de la Cruz Sánchez-Escobedo, Díaz-Casero, Díaz-Aunión } \\
\text { and Hernández-Mogollón (2014) }\end{array}$ & 9 & AEJ \\
\hline 10. & Phipps and Prieto (2015) & \\
\hline
\end{tabular}

Source: authors' analysis from Google Scholar. 
Table 4. Research papers in the category of Entrepreneurial Mechanism

\begin{tabular}{|c|l|r|l|}
\hline Sl. No. & \multicolumn{1}{|c|}{ Author(year) } & Cites & \multicolumn{1}{|c|}{ Journal } \\
\hline 1. & Ahl (2006) & 1288 & ETP \\
\hline 2. & Gupta, Turban, Wasti and Sikdar (2009) & 565 & ETP \\
\hline 3. & Maes, Leroy and Sels (2014) & 69 & EMJ \\
\hline 4. & Armstrong (2011) & 10 & JDE \\
\hline 5. & Jin, Gilmartin, Sheppard and Chen (2015) & 9 & JEEN \\
\hline 6. & $\begin{array}{l}\text { Alonso-Galicia, Fernández-Pérez, Rodríguez-Ariza and } \\
\text { Fuentes-Fuentes (2015) }\end{array}$ & JMP \\
\hline 7. & Perez-Quintana, Hormiga, Martori and Madariaga (2017) & 3 & IJGE \\
\hline
\end{tabular}

Source: authors' analysis from Google Scholar.

Table 5. Research papers in the category of Individual level Variables

\begin{tabular}{|c|l|r|l|}
\hline SI. No. & \multicolumn{1}{|c|}{ Author(year) } & Cites & \multicolumn{1}{|c|}{ Journal } \\
\hline 1. & Zhao, Seibert and Hills (2005) & 1829 & JAP \\
\hline 2. & Díaz-García and Jiménez-Moreno (2010) & 242 & IEMJ \\
\hline 3. & Yordanova and Tarrazon (2010) & 70 & JDE \\
\hline 4. & Hirschi and Fischer (2013) & 30 & CDI \\
\hline 5. & Strobl, Kronenberg and Peters (2012) & 18 & IJESB \\
\hline 6. & Anggadwita and Dhewanto (2016) & 16 & IJESB \\
\hline 7. & Dinc and Budic (2016) & 9 & EJBE \\
\hline 8. & Mehtap, Pellegrini, Caputo and Welsh (2017) & 6 & IJEBR \\
\hline
\end{tabular}

Source: authors' analysis from Google Scholar.

Even though the research papers were divided into 5 major categories and 24 sub-categories, they are interlinked and many papers may have contribution to even more than one categories. So, the papers were mainly divided on the major focus of the research paper and its outcomes. The flow-chart linking the interconnectivity of various areas can be portrayed as on Figure 1.

Figure 1. Categories of papers from citation analysis

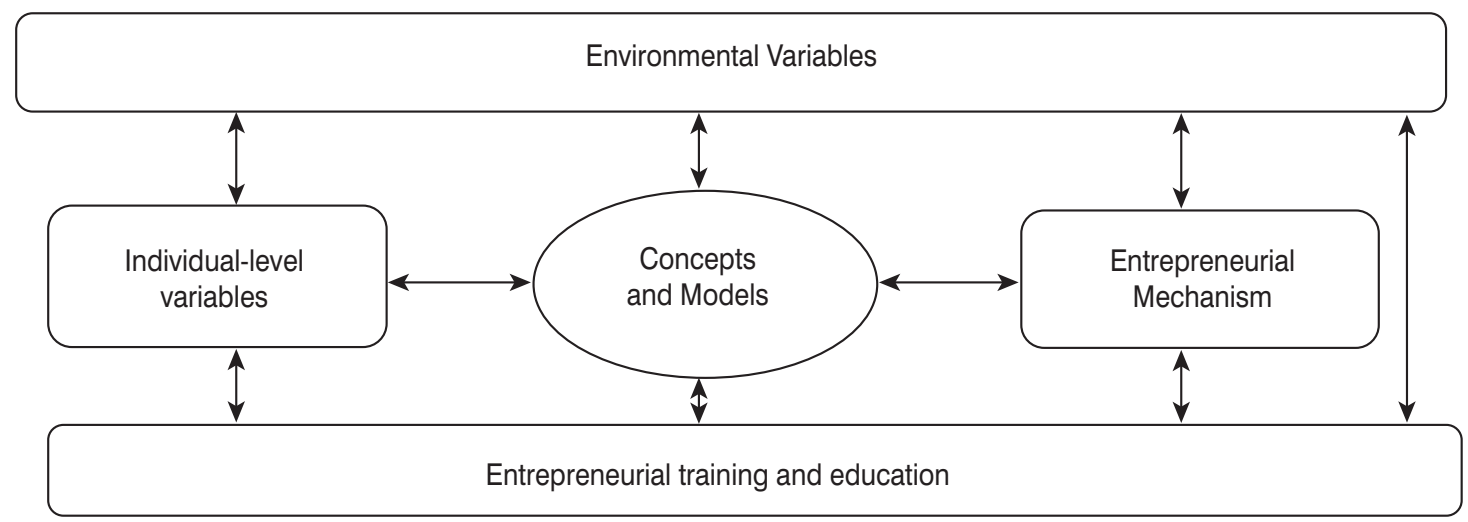

Source: ???? 


\section{Literature Review}

An extensive literature review was conducted and the papers were categorized and reviewed as follows:

\subsection{Concepts and models:}

In the area of concepts and models the papers were shortlisted on the basis of the criteria as follows:

\section{i. $\quad$ Mediators and moderators}

Haus et al. (2013) in their study attempted to analyze the mediating effect of motivational constructs on the relationship of gender and entrepreneurial intentions. However, huge differences in actual creation of ventures by men and women cannot be explained by the gender differences in entrepreneurial intentions and the motivational constructs as they were relatively very small. Analysis also shows differences in the relationship of gender and entrepreneurial intentions in different geographical locations like Europe and the U.S.

Tsai et al. (2016) in this paper analyzed perceived opportunity, fear of failure and gender as mediators in the relationship between perceived capability and entrepreneurial intentions. Findings portray that entrepreneurial intention is positively affected by perceived capability when it is mediated through perceived opportunity. Fear of failure has a low mediating effect in linking perceived capability and entrepreneurial intention. The mediating effect of perceived opportunity is partially moderated by gender. Future research on entrepreneurial intention should focus on economic development status of various countries to gain more insight on the matter.

BarNir et al. (2011) in this paper explored the effects of role-models and selfefficacy on the entrepreneurial intentions of women. Results show that role models positively influence the entrepreneurial intentions and self-efficacy mediated the moderating effects of gender. Especially in the case of women role models had a very strong influence on self-efficacy which in turn enhanced the entrepreneurial intentions. Future research can be conducted on identifying the other antecedents of entrepreneurial intentions.

\section{ii. Configuration of antecedents}

Varamäki et al. (2015) in this paper analyzed how young people develop entrepreneurial potential. The development and changes in entrepreneurial intentions of individuals is analyzed by investigating the antecedents of intentions. The impact of entrepreneurial education is also analyzed. Overall, the entrepreneurial intentions of higher education students decreased over time. Students with high initial level of intentions had the most declines in intentions. A positive role was played by Changes in attitudes and perceived behavioral control. Attitude plays a major role in influencing both intentions and perceived behavioral control of individuals. The further analysis of model suggests gender differences in development of entrepreneurial intentions. Future research is required on entrepreneurial intentions using versatile samples comprising of students from universities from all over the world.

Srivastava and Misra (2017) in this study tried to identify the antecedents of entrepreneurial intentions of young women in India because currently Indian Government is heavily emphasizing on women's participation in the mainstream of economic activities in the country. Future research can be directed in the following ways: Firstly, the study can be extended to a wider geographical area in India with a large sample size to make the findings more meaningful and conclusive. Secondly, the impact of cultural differences on entrepreneurial intentions of women in India can be further investigated. Thirdly, the current status and degree of social legitimation of women entrepreneurship in India can also be further investigated. Finally, the current status of entrepreneurship education in India and identification of suitable contents that trigger the intentions and rate of start-ups by women can be the area of future research.

\section{iii. General test of the theory}

Smith et al. (2016) in this paper investigated the impact of gender and creativity on entrepreneurial intentions by conducting empirical studies. The findings show that entrepreneurial intentions are positively affected by creativity and the effect is direct. Gender did not have effect upon 
the entrepreneurial intentions directly but showed an interaction with creativity, which in turn influenced the entrepreneurial intentions. Future researchers must strive to create customized training programs to enhance the entrepreneurial intentions of women.

Kickul et al. (2008) in this paper conducted an empirical study of more than 5000 students to obtain data about role models, self-efficacy and entrepreneurial intentions. Results show that engaging in a job outside school had a greater impact on boys as compared to girls in forming entrepreneurial career intentions. Self-efficacy had a greater impact on girls compared to boys in their decision of starting a new entrepreneurial venture. Future longitudinal research is required to develop the concept further.

\section{iv. Specific intentions}

Sweida and Reichard (2013) in their paper analyzed the effects of implicit and explicit gender stereotypes on high-growth entrepreneurial intentions of women to increase women's entrepreneurial intention and to engage them in high-growth venture creation. Future research could focus on using an alternative sampling frame particularly engaging in "intervention" studies aimed at increasing the entrepreneurial intent of women through the management stereotypes of gender and high-growth entrepreneurship.

\section{v. New theoretical framework}

Zeffane (2015) in his paper attempted to review recent literature to shed light on risk-taking gender and trust in context of entrepreneurship to frame a theoretical model. Risk taking ability is found to be one of the major reasons for this gender disparity. This disparity may also be the result of gender differences in level of trust. Future researchers may test the validity of the model framed in the study. Use of technique of structural equation modeling on this model may prove beneficial.

Boyd and Vozikis (1994) analyzed the social, political, and economic variables, i.e., contextual factors of entrepreneurship. This paper further investigates on Bird's research of entrepreneurial intentions by stating that self-efficacy acts as a pre-cursor of entrepreneurial intentions and leads to establishment of new ventures. This research has provided a model to test for future researchers.

\section{vi. Additional variables}

Kennedy and Drennan (2002) in this paper analyzed factors related to lower entrepreneurial intentions in women that have been identified from earlier studies. Further research has been conducted on the areas on which previous analysis has been incomplete or inadequate. Research suggests that personal background and attitudinal variables can be connected to lower level entrepreneurial intentions and negatively influence entrepreneurial actions. Future researchers should focus on role models, networks and life roles in order to better explain female entrepreneurial intentions.

\section{vii. Methodology used}

Wheadon and Duval-Couetil (2017) in this paper tried to analyze the process of generation of innovative ideas which are basic to entrepreneurial process and are essential to research on entrepreneurship. The findings show that some processes lead to barrier and affect the idea generation process but the tool of critical theory and reflexivity can reduce its effect. Critical theory can help in inducing diversity and innovation practices in the entrepreneurial process. Future researchers can expand the research to cover a wider variety of population and analyze further applications of critical theory and reflexivity.

\subsection{Entrepreneurial mechanism}

In the area of entrepreneurial mechanism the papers were shortlisted on the basis of the criteria as follows:-

\section{i. Longitudinal studies}

Alonso-Galicia et al. (2015) did the analysis at the structural level. According to it, males are more influenced than females by favorable attitude towards entrepreneurship and thus males have stronger entrepreneurial intentions than women in academics. The influence of family and close social groups is perceived differently by men and women. They are influenced by the way in which the support for academic attitudes and perceptions of control influence the decision to become an entre- 
preneur. Longitudinal studies would help to better analyze the variables included in the study and provide a clear idea on their determinants, processes and results.

Perez-Quintana et al. (2017) in this paper analyzed how the gender-role orientation influences an individual to start a new venture. The role of sex in entrepreneurship is analyzed. The findings show that gender-role orientation can be used as a tool to elaborate entrepreneurial decision precisely. The findings also show that masculine entrepreneurial intentions are more than the feminine entrepreneurial decisions. Future research must focus on the effect of the societal construct on the entrepreneurial decision making process to find the impact of society on entrepreneurship.

Armstrong (2011) attempted to find factors affecting venture creation decision by analyzing the relationship between gender and entrepreneurial intentions. The findings of this study portray that the different roles that women play help them in recognizing entrepreneurial opportunities, which explains beliefs-attitudes and intentionsbehavior model of intentionality. Women can also judge the likelihood of success of their venture from the roles they play in the enterprise. Future researchers should study cognitions and affects among business students in other related types of settings to test the generalizability of this study's findings (Bass and Firestone, 1980).

\section{ii. Entrepreneurial Pathway}

Jin et al. (2015) in this paper analyzed the gender gap in entrepreneurial pathways to better understand the similarities and dissimilarities in entrepreneurial characteristics. The results portray that entrepreneurial intentions of engineering students are lower than the business students. Women have shown lower entrepreneurial intentions than men in both categories of students. Engineering students, who had fewer interactions with their mentors, were less into entrepreneurial activities than their business student counterparts, which led to the difference of entrepreneurial intentions. Future research could compare engineering and business students prior to college to analyze how college contexts such as major of subjects may influence the entrepreneurial intentions of students.
Ahl (2006) in this paper showed, as an earlier research has brought to light, that women are inferior to men in the field of entrepreneurship or at best that women can complement the abilities of men, which is not the case in reality. This paper shows that if we redefine the path of being an entrepreneur for a woman then the results can be really positive. Implementation of feminist theory and critical theory will make the women entrepreneurial research even more productive in the future.

\section{iii. Variables affecting the process}

Gupta et al. (2009) in this paper analyzed the role of socially constructed Gender stereotypes in entrepreneurship and their influence on entrepreneurial intentions was estimated. Results brought to light reveal that although both genders perceive entrepreneurs to have male characteristics (masculine gender-role stereotype), only women perceived the opposite.

Maes et al. (2014) in this paper attempted to better understand and expand on the deeper-level measurement model in Theory of Planned Behavior. Female students are also not much influenced by their role models. Future researchers must take into consideration the hindrances due to gender differences as a potential explanation for differences in level of new venture creation in males and females.

\subsection{Entrepreneurial training and education}

In the area of entrepreneurial training and education the papers were shortlisted on the basis of the criteria as follows:

\section{i. Level of education}

Wilson et al. (2007) in this paper analyzed the relationship between self-efficacy, gender, and entrepreneurial intentions for two sample groups (adolescents and MBA students). Both groups showed similar entrepreneurial self-efficacy based on gender and support prior research suggesting that self-efficacy and career intentions are interrelated. The study should be replicated among undergraduate-level students to gain deeper knowledge on how the relationships between gender, self-efficacy, and entrepreneurial intentions changes over time. Longitudinal research is needed in this area. 
Wilson et al. (2009) did a comprehensive analysis and the results of analysis show the importance of entrepreneurial self-efficacy in shaping entrepreneurial interest leading to venture creation. Women were more positively influenced by entrepreneurial education and showed higher levels of selfefficacy than men. A longitudinal study is needed to establish the causal effect of gender and self-efficacy on entrepreneurial actions.

\section{ii. Entrepreneurial training and education results}

Pruett (2012) examined the data from participants of workshops on entrepreneurship education and determined the impact. He also tested the impact of incorporating social and psychological factors in entrepreneurial intentions model. It was established that entrepreneurial intentions were positively impacted by the workshop series, while the role models and family support did not significantly impact entrepreneurial intentions. It was also observed that the interest in entrepreneurship was approximately the same for both genders. Future empirical studies on different types of approaches to entrepreneurial education will help to find out what works out best and in which conditions or situations in entrepreneurship.

Westhead and Solesvik (2016) showed that in line with future research men had higher entrepreneurial intentions than women; however, women with high alertness skill had high intensity of entrepreneurial intentions. Both male entrepreneurial education and non-entrepreneurial education students citing the risk perception skill had higher entrepreneurial intentions. Future research in the form of cross-sectional and longitudinal studies of entrepreneurial education of different universities from in different geographical and cultural areas is required to further establish the concept.

\section{iii. Entrepreneurial training and education evaluation}

Rauth Bhardwaj (2014) in this paper attempted to find out how the performance of women entrepreneurs is influenced by entrepreneurial education and training in skills. The findings show that entrepreneurial education motivates women to start new ventures. Entrepreneurial education helps them to find new ideas and use them in new venture creation. The major hindrances were time availability and resources, due to which women entrepreneurs find it difficult to train themselves, and are unaware of recent developments in technology and ongoing trends in the market. The study findings suggest that potential women entrepreneurs must be provided with professional training and skill development program that would enhance the probability they would start a business.

Zhang et al. (2014) in this paper conducted an empirical study on 494 university students to find out the impact of entrepreneurial education and earlier entrepreneurial experience upon the entrepreneurial intentions. Results show that entrepreneurial education positively influenced the entrepreneurial intentions and in the case of students with technical education men had higher entrepreneurial propensity than women. Future research should focus on trying to find out measures to strengthen the entrepreneurial education to imbibe entrepreneurial intentions in more students.

\section{iv. Comparative analysis}

Entrialgo and Iglesias (2016) showed that entrepreneurial education strengthens the knowledge and thus leads to positive perceptions towards entrepreneurship. The analysis must be conducted on entrepreneurial intentions before and after having education of venture creation.

Bae et al. (2014) after extensive research found that correlation between entrepreneurship education and entrepreneurial intentions significantly greater than the correlation between business education and entrepreneurial intentions. Future research is required to extend current efforts to identify more important and informative perspectives. Future studies can, for example, measure the entrepreneurial intentions by specifically emphasizing on growth- and independence-oriented intentions.

\subsection{Individual-level variables}

In the area of individual-level variables the papers were shortlisted on the basis of the criteria as follows:

\section{i. Personality/psychology factors}

Hirschi and Fischer (2013) examined whether entrepreneurial intentions are 
affected by work values of individuals. Entrepreneurial intentions are positively affected by self-enhancement and openness to change while conservation negatively affects entrepreneurial intentions. Future research required on how values have different effects on entrepreneurial intentions of men and women.

Strobl et al. (2012) in his research conducted a survey which was carried out among university students and revealed that male students show more positive attitudes towards entrepreneurship and much more specific entrepreneurial intentions than females. Further survey and research concerning start-up guidance and its effect need to be conducted and it needs to be analyzed whether genders react differently towards the same start-up guidance.

\section{ii. Background factors}

Anggadwita and Dhewanto (2016) analyzed entrepreneurial intentions of women involved in medium and small scale enterprises by taking into account their attitude and social perceptions. The findings reveal that personal attitude plays a mediating role on entrepreneurial intentions of women and is significantly influenced by psychological characteristics and individual competencies. Psychological characteristics also have direct impact on competencies of the individual. Future research needs to be carried out to detect other factors that influence entrepreneurial intentions of women. Socio-cultural values, environmental factors, and educational background can be some such factors.

\section{iii. Specific subsamples}

Yordanova and Tarrazon (2010) tested a sample of students of an university in Bulgaria to come up with a conceptual framework to understand how entrepreneurial intentions are influenced by gender. Further research is required to formulate policy measures that encourage start-ups by women taking into consideration the variables like perceived behavioral control, attitudes, and subjective norms.

Dinc and Budic (2016) examined the factors that influence entrepreneurial intentions of women in the Federation of Bosnia and Herzegovina. The findings show a positive and significant influence of personal attitude and perceived behavioral control on entrepreneurial intention.
Women with a positive outlook towards entrepreneurship develop strong entrepreneurial intentions. Future research surveys with higher sample sizes and more participants of different age groups from different geographical location may provide a more clear idea.

Zhao et al. (2005) conducted a structural equation modeling of a sample of 265 MBA students across 5 universities and included that in the analysis. Future research is required on the content, design, and delivery method of each entrepreneurial education program.

\section{iv. Perceived barriers}

Mehtap et al. (2017) attempted to measure the impact of socio-cultural barriers on new venture creation by the Jordanian population by taking entrepreneurial education into consideration. The findings suggest that the entrepreneurial training and education can reduce the impact of barriers on the entrepreneurial process. But if the entrepreneurial education lacks support for potential entrepreneurs then it can negatively affect the mindset of the future entrepreneurs and thus decrease their intentions. Future researchers should not focus only on business students; instead, a sample must be taken from different disciplines to know the impact of entrepreneurial education on different categories of students.

Díaz-García and Jiménez-Moreno, J. (2010) in their research have shown that men with greater harmony among masculine and entrepreneurial attributes have a higher entrepreneurial intention. Also, feminine attributes are considered favorable to be successful entrepreneurs by both men and women.

\subsection{Environmental Variables}

In the area of environmental variables the papers were shortlisted on the basis of the criteria as follows:-

\section{i. $\quad$ Cross-cultural studies}

Iakovleva and Solesvik, M. Z. (2014) analyzed the personal initiative taking in the process. Russian respondents showed less intensity of entrepreneurial intentions as compared to the Ukrainian respondents. Gender plays a moderating role between perceived behavioral control and intentions, but does not affect attitude or 
subjective norms. Future research should take into account the cultural differences between the countries considered and larger samples ought to be taken from other countries to further establish the concept.

De La Cruz et al. (2014) studied socioeconomic and psychosocial factors to better understand the differences in gender in the level of entrepreneurial intentions across different countries. Future researchers should address this issue that explanatory power of the model proposed decreases as the degree of economic development increases. Moreover the study is also less conclusive for women than men.

\section{ii. External Motivation}

Austin and Nauta (2016) analyzed the effect of exposure to entrepreneurial role-model and self-efficacy on entrepreneurial intentions of women. Results reveal that women who had exposure to at least one entrepreneurial role model had more entrepreneurial intentions and in line with what Social Cognitive Career Theory suggests, self-efficacy plays a mediating role on the role-model exposure and entrepreneurial intentions. Future research should be directed towards developing mentor programs and internship opportunities for potential women entrepreneurs.

\section{iii. Institutional variables}

Scherer et al. (1990) analyzed potential differences between males and females on a set of entrepreneurial career preference variables that describe social learning effects on the individuals. The results found that when comparing males with females, males tend to have a higher affinity for entrepreneurship than females. The motivation for entering an entrepreneurial career plays a key role. Self-efficacy is also found to be a differentiating factor between males and females, while the education and training aspirations play a minor role. From the analysis it can be concluded that the preference of becoming an entrepreneur is considerably affected by social learning differences. As Birley (1989) suggested, the entrepreneurial decision is highly influenced by culture. Women need specific opportunities to develop the feelings of competency and expect to succeed in establishing and successfully operating a new venture.

\section{iv. Political Motivation}

Phipps and Prieto (2015) attempted to analyze and find out which dimensions of political skill are more strongly related to entrepreneurial intentions. Out of all dimensions, networking ability and social astuteness had the strongest influence on entrepreneurial intentions. Tests also revealed that female students scored higher than male students in each dimension of political skill in regards to entrepreneurial intentions. Future research should continue to uncover the factors that influence entrepreneurial intentions and behavior. Their findings would allow to frame more customized training and development programs for potential and budding entrepreneurs.

\section{v. Cultural background}

Gallant et al. (2010) conducted an empirical research on females who opted for business studies in Dubai, to better describe entrepreneurial intentions of females in Arabic cultural context. The results show positivity and enthusiasm among female students in Dubai regarding the importance of entrepreneurial education from university which fosters their interest towards entrepreneurial venture creation.

Liñán and Chen (2009) tested the adequacy of the Entrepreneurial Intention model in a cross-country model and assess the adequacy of a newly developed instrument - the Entrepreneurial intentions questionnaire, EIQ - in different cultural settings. Results show that cultural and social particularities would effect on the entrepreneurial intentions of individual to a certain extent. The scale developed can be tested in various cultural contexts of different countries to analyze their entrepreneurial intentions.

\section{vi. Social approach}

Santos et al. (2016) analyzed the relationship between gender differences and the social environment and how they lead to different levels of entrepreneurial intention. The results show that men and women have a similar process of formation of entrepreneurial intentions but still men consistently exhibit more favorable intentions than women because of the varying 
societal norms which occur more favorable towards men. Future studies and analysis of samples coming from different countries or geographic location are required to consolidate the understanding of the concept.

Langowitz and Minniti (2007) in their study did a research on behavior of individuals from 21 countries to find out why the level of proclivity of women was lower than that of men for entrepreneurial activities. They found that due to their past social experiences and current trends, women shared a belief that the conditions favored men in entrepreneurship and, in consequence, women developed a lower self confidence which resulted in less entrepreneurial ventures by women.

Liñán and Santos (2007) in their research have shown that the social capital helps in the decision making process of being an entrepreneur. The research shows that cognitive social capital affects the entrepreneurial intentions of women. Future research should focus on specific value system in the external environment and personal characteristics.

\section{Research Limitations and Future research}

This study is not without limitations, which are associated with the methodology used. Firstly, despite extensive efforts of the authors, the literature search may have failed to capture all entrepreneurial intentions papers. In particular, the researchers excluded contributions such as chapters in published books. Secondly, despite every precaution taken, the researcher recognizes his subjectivity regarding the classification of papers.

For future research there remains plenty of room to integrate themes across each category in the future by using various methods, such as experiential research designs. For instance, the areas of the concepts and entrepreneurial mechanism categories could be jointly addressed to identify causal order in the entrepreneurial process (Kessler and Frank, 2009).

In future research, analytic hierarchy process (AHP) analysis can be conducted to find out which categories and their sub-categories of papers had the highest impact, based on their citations. The categories can then be ranked according to their priority.

\section{Conclusion}

The categories can be applied to do research on life of women entrepreneurs to increase their efficiency and can also consider women aspiring to be entrepreneurs. Training sessions can be arranged for women and girls in higher education to boost their self-confidence, thus guiding them better towards their future participation in the field of entrepreneurship.

Entrepreneurial intention of women is a field of research from the broad concept of entrepreneurship. The main gist of this paper lies in segregation of research articles that were published in entrepreneurial intentions of women from 1990 to 2017. Citation analysis and overall concept relevance analysis have been conducted to review the papers. The five lines of research identified in the field are equally important. Still plenty of room remains for research on additional new categories to establish the concept even further. The field has constantly evolved since it was first conceived, and is still evolving through contributions of new researchers. From the literature review of the papers in the five distinct areas of women entrepreneurial intention it can be established that these play huge roles in shaping the entrepreneurial intentions of women. Cultural and Social particularities would influence the entrepreneurial intentions of women. Also, opportunity and opportunity recognition are major reasons of motivation which determine intentions. Self-efficacy plays a major role in taking the decision to start the entrepreneurship. Entrepreneurial skill perceptions do have a very significant effect over the three motivational constructs considered (personal attraction, subjective norms and perceived behavioral control). Both closer and social value perceptions of entrepreneurship have a positive effect over the perceived entrepreneurial skills. Entrepreneurship education could be a very relevant instrument to promote a more positive entrepreneurial culture in the society.

\section{References}

Ahl, H. (2006). Why research on women entrepreneurs needs new directions. Entrepreneurship theory and practice, 30(5), 595-621.

Ajzen, I. (1991). The theory of planned behavior. Organizational Behavior and Human Decision Processes, 50(2), 179-211. 
Alonso-Galicia, P.E., Fernández-Pérez, V., Rodríguez-Ariza, L. and Fuentes-Fuentes, M.D.M. (2015). Entrepreneurial cognitions in academia: exploring gender differences. Journal of Managerial Psychology, 30(6), 630-644.

Anggadwita, G. and Dhewanto, W. (2016). The influence of personal attitude and social perception on women entrepreneurial intentions in micro and small enterprises in Indonesia. International Journal of Entrepreneurship and Small Business, 27(2-3), 131-148.

Armstrong, C.E. (2011). Thinking and slacking or doing and feeling? Gender and the interplay of cognition and affect in new venture planning. Journal of Developmental Entrepreneurship, 16(02), 213-226.

Austin, M.J. and Nauta, M.M. (2016). Entrepreneurial role-model exposure, self-efficacy, and women's entrepreneurial intentions. Journal of Career Development, 43(3), 260-272.

Bae, T.J., Qian, S., Miao, C. and Fiet, J.O. (2014). The relationship between entrepreneurship education and entrepreneurial intentions: A meta-analytic review. Entrepreneurship theory and practice, 38(2), 217-254.

BarNir, A., Watson, W.E. and Hutchins, H.M. (2011). Mediation and moderated mediation in the relationship among role models, self-efficacy, entrepreneurial career intention, and gender. Journal of Applied Social Psychology, 41(2), 270-297.

Bird, B. (1988). Implementing entrepreneurial ideas: the case for intention. Academy of Management Review, 13(3), 442-453.

Boyd, N.G. and Vozikis, G.S. (1994). The influence of self-efficacy on the development of entrepreneurial intentions and actions. Entrepreneurship theory and practice, 18(4), 63-77.

de la Cruz Sánchez-Escobedo, M., Díaz-Casero, J.C., Díaz-Aunión, Á.M. and Hernández-Mogollón, R. (2014). Gender analysis of entrepreneurial intentions as a function of economic development across three groups of countries. International Entrepreneurship and Management Journal, 10(4), 747-765.

Díaz-García, M.C. and Jiménez-Moreno, J. (2010). Entrepreneurial intention: the role of gender. International Entrepreneurship and Management Journal, 6(3), 261-283.

Dind, M.S. and Budic, S. (2016). The impact of personal attitude, subjective norm, and perceived behavioural control on entrepreneurial intentions of women. Eurasian Journal of Business and Economics, 9(17), 23-35.

Entrialgo, M. and Iglesias, V. (2016). The moderating role of entrepreneurship education on the antecedents of entrepreneurial intention. International Entrepreneurship and Management Journal, 12(4), 1209-1232.
Gallant, M., Majumdar, S. and Varadarajan, D. (2010). Outlook of female students towards entrepreneurship: An analysis of a selection of business students in Dubai. Education, Business and Society: Contemporary Middle Eastern Issues, 3(3), 218-230.

Gupta, V.K., Turban, D.B., Wasti, S.A. and Sikdar, A. (2009). The role of gender stereotypes in perceptions of entrepreneurs and intentions to become an entrepreneur. Entrepreneurship Theory and Practice, 33(2), 397-417.

Haus, I., Steinmetz, H., Isidor, R., \& Kabst, R. (2013). Gender effects on entrepreneurial intention: A meta-analytical structural equation model. International Journal of Gender and Entrepreneurship, 5(2), 130-156.

Hirschi, A. and Fischer, S. (2013). Work values as predictors of entrepreneurial career intentions. Career Development International, 18(3), 216-231.

Iakovleva, T. and Solesvik, M.Z. (2014). Entrepreneurial intentions in post-Soviet economies. International Journal of Entrepreneurship and Small Business, 21(1), 79-100.

Jin, Q., Gilmartin, S.K., Sheppard, S.D. and Chen, H.L. (2015). Comparing Engineering and Business Undergraduate Students' Entrepreneurial Interests and Characteristics. The Journal of Engineering Entrepreneurship, 6(2), 1-24.

Jones, M.V., Coviello, N. and Tang, Y.K. (2011). International. Entrepreneurship research (1989-2009): A domain ontology and thematic analysis. Journal of Business Venturing, 26(4), 632-659.

Kennedy, J. and Drennan, J. (2002). Entrepreneurial intentions of women. Small Enterprise Research, 10(1), 75-87.

Kessler, A. and Frank, H. (2009). Nascent entrepreneurship in a longitudinal perspective: The impact of person, environment, resources and the founding process on the decision to start business activities. International Small Business Journal, 27(6), 720-742.

Kickul, J., Wilson, F., Marlino, D. and Barbosa, S.D. (2008). Are misalignments of perceptions and selfefficacy causing gender gaps in entrepreneurial intentions among our nation's teens? Journal of Small Business and Enterprise Development, 15(2), 321-335.

Kolvereid, L. (1996a). Organizational employment versus self-employment: reasons for career intentions. Entrepreneurship: Theory and Practice, 20(3), 23-31.

Kolvereid, L. (1996b). Prediction of employment status choice intentions. Entrepreneurship: Theory and Practice, 21(1), 47-57.

Kurczewska, A. and Białek, J. (2014). Is the Interplay between Self-Efficacy and Entrepreneurial 
Intention Gender-Dependent? Argumenta Oeconomica, 2(33), 23-38.

Langowitz, N. and Minniti, M. (2007). The entrepreneurial propensity of women. Entrepreneurship Theory and Practice, 31(3), 341-364.

Liñán, F. and Santos, F.J. (2007). Does social capital affect entrepreneurial intentions?. International Advances in Economic Research, 13(4), 443-453.

Linan, F. (2008). Skill and value perceptions: how do they affect entrepreneurial intentions? International Entrepreneurship and Management Journal, 4(3), 257-272.

Liñán, F. and Chen, Y.W. (2009). Development and Cross-Cultural application of a specific instrument to measure entrepreneurial intentions. Entrepreneurship Theory and Practice, 33(3), 593-617.

Lee, S.H. and Wong, P.K. (2004). An exploratory study of technopreneurial intentions: a career anchor perspective. Journal of Business Venturing, 19(1), 7-28.

Maes, J., Leroy, H. and Sels, L. (2014). Gender differences in entrepreneurial intentions: A TPB multi-group analysis at factor and indicator level. European Management Journal, 32(5), 784-794.

Mehtap, S., Pellegrini, M.M., Caputo, A. and Welsh, D.H. (2017). Entrepreneurial intentions of young women in the Arab world: Socio-cultural and educational barriers. International Journal of Entrepreneurial Behavior \& Research, 23(6), 880-902.

Perez-Quintana, A., Hormiga, E., Martori, J.C. and Madariaga, R. (2017). The influence of sex and gender-role orientation in the decision to become an entrepreneur. International Journal of Gender and Entrepreneurship, 9(1), 8-30.

Phipps, S.T. and Prieto, L.C. (2015). Politicking and Entrepreneurship: Determining the Critical Political Skill Dimensions for High Entrepreneurial Intentions. Academy of Entrepreneurship Journal, 21(2), 73.

Podsakoff, P., MacKenzie, S., Bachrach, D. and Podsakoff, N. (2005). The influence of management journals in the 1980s and 1990s. Strategic Management Journal, 26, 473-488.

Pruett, M. (2012). Entrepreneurship education: Workshops and entrepreneurial intentions. Journal of Education for Business, 87(2), 94-101.

Rauth Bhardwaj, B. (2014). Impact of education and training on performance of women entrepreneurs: A study in emerging market context. Journal of Entrepreneurship in Emerging Economies, 6(1), 38-52.

Santos, F.J., Roomi, M.A. and Liñán, F. (2016). About gender differences and the social environment in the development of entrepreneurial intentions. Journal of Small Business Management, 54(1), 49-66.
Scherer, R.F., Brodzinski, J.D. and Wiebe, F.A. (1990). Entrepreneur career selection and gender: A socialization approach. Journal of Small Business Management, 28(2), 37.

Shapero, A. (1984). The entrepreneurial event. In: C.A. Kent (ed.), The environment for entrepreneurship. Lexington: Lexington Books.

Smith, R.M., Sardeshmukh, S.R. and Combs, G.M. (2016). Understanding gender, creativity, and entrepreneurial intentions. Education + Training, 58(3), 263-282.

Srivastava, S. and Misra, R. (2017). Exploring antecedents of entrepreneurial intentions of young women in India: A multi-method analysis. Journal of Entrepreneurship in Emerging Economies, 9(2), 181-206.

Strobl, A., Kronenberg, C. and Peters, M. (2012). Entrepreneurial attitudes and intentions: assessing gender specific differences. International Journal of Entrepreneurship and Small Business, 15(4), 452-468.

Sweida, G.L. and Reichard, R.J. (2013). Gender stereotyping effects on entrepreneurial self-efficacy and high-growth entrepreneurial intention. Journal of Small Business and Enterprise Development, 20(2), 296-313.

Tranfield, D., Denyer, D. and Smart, P. (2003). Towards a methodology for developing evidence-informed management knowledge by means of systematic review. British Journal of Management, 14(3), 207-222.

Tsai, K.H., Chang, H.C. and Peng, C.Y. (2016). Refining the linkage between perceived capability and entrepreneurial intention: Roles of perceived opportunity, fear of failure, and gender. International Entrepreneurship and Management Journal, 12(4), 1127-1145.

Varamäki, E., Joensuu, S., Tornikoski, E. and Viljamaa, A. (2015). The development of entrepreneurial potential among higher education students. Journal of Small Business and Enterprise Development, 22(3), 563-589.

Westhead, P. and Solesvik, M. Z. (2016). Entrepreneurship education and entrepreneurial intention: Do female students benefit? International Small Business Journal, 34(8), 979-1003.

Wheadon, M. and Duval-Couetil, N. (2017). Entrepreneuring gender diversity in entrepreneurship through critical theory and reflexivity. International Journal of Gender and Entrepreneurship, 9(2), 188-202.

Wilson, F., Kickul, J. and Marlino, D. (2007). Gender, entrepreneurial self-efficacy, and entrepreneurial career intentions: implications for entrepreneurship education. Entrepreneurship Theory and Practice, 31(3), 387-406. 
Wilson, F., Kickul, J., Marlino, D., Barbosa, S.D. and Griffiths, M.D. (2009). An analysis of the role of gender and self-efficacy in developing female entrepreneurial interest and behavior. Journal of Developmental Entrepreneurship, 14(02), 105-119.

Yordanova, D.I. and Tarrazon, M.A. (2010). Gender differences in entrepreneurial intentions: Evidence from Bulgaria. Journal of Developmental Entrepreneurship, 15(03), 245-261.
Zhang, Y., Duysters, G. and Cloodt, M. (2014). The role of entrepreneurship education as a predictor of university students' entrepreneurial intention. International Entrepreneurship and Management Journal, 10(3), 623-641.

Zeffane, R. (2015). Gender, trust and risk-taking: a literature review and proposed research model. Journal of Enterprising Communities: People and Places in the Global Economy, 9(3), 221-232. 